\title{
Organogold Chemistry: III Applications
}

\author{
$R$ V Parish \\ Department of Chemistry, UMIST, PO Box 88, Manchester M60 1QD, UK
}

\begin{abstract}
Gold forms a wide variety of organic derivatives, whose preparation, structures and reactions were reviewed in Parts I and II. Here some applications of the compounds are discussed, in the areas of organic synthesis, catalysis, liquid crystals, MOCVD, luminescence, and chemotherapy.
\end{abstract}

Previous articles in this series have reviewed the diverse types of known organogold compounds (1) and the varied reactions which they undergo (2). Compared to those of other precious metals, compounds of gold feature in rather few applications, although interest has increased over recent years. In this contribution, these applications are reviewed, together with some suggestions for further developments.

\section{ORGANIC SYNTHESIS}

Some organogold compounds undergo reactions which give organic products which are useful or which cannot readily be obtained in other ways. For example, di-arylgold(III) compounds undergo reductive elimination stimulated by addition of a tertiary phosphine, to give symmetric or unsymmetric diaryls (3). One of the aryl groups must have a substituent which also binds to the gold atom, in order to stabilize the di-aryl compound. A variety of other substituents may be present in either aryl. Some examples are shown in Box 1. Arylsubstituted ketones may be obtained similarly (4).

The formation of homoallyl alcohols from aldehyde-insertion into the gold-carbon bonds of allyl, methallyl or crotyl complexes (5) is also useful, although isomerization sometimes means that the product is not that immediately expected (Box 2). The cleanest reactions are obtained when an organic proton source is added, such as $\mathrm{CH}_{2}(\mathrm{CN})_{2}$

An additional reaction is that of a gold(I) ketonyl complex with another ketone in the presence of a Lewis acid $\left(e g \mathrm{TiCl}_{4}\right)$, to give a keto-enol (Equation 1) (6). This reaction is thought to proceed via transmetallation from gold to titanium, and has been studied for gold complexes containing $-\mathrm{CH}_{2} \mathrm{C}(\mathrm{O}) \mathrm{Ph}$,

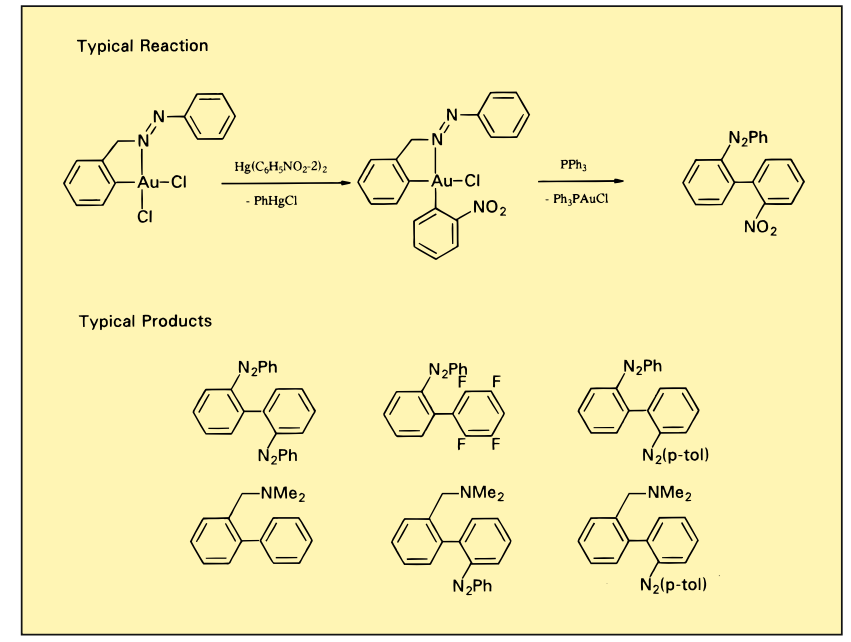

Box 1 Formation of biaryls, Ar-Ar'

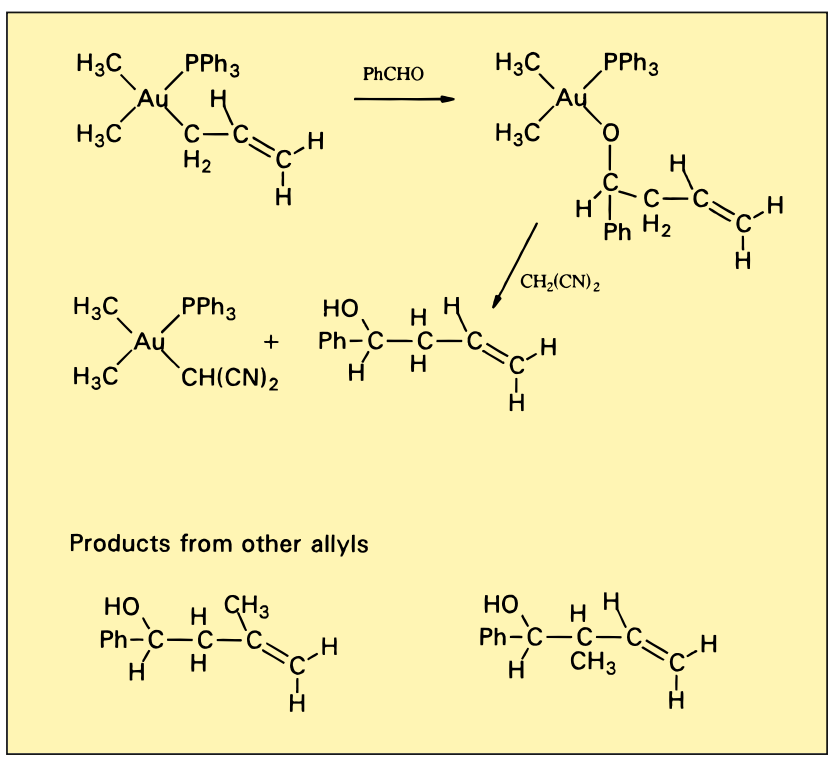

Box 2 Formation of homoallylic alcohols 


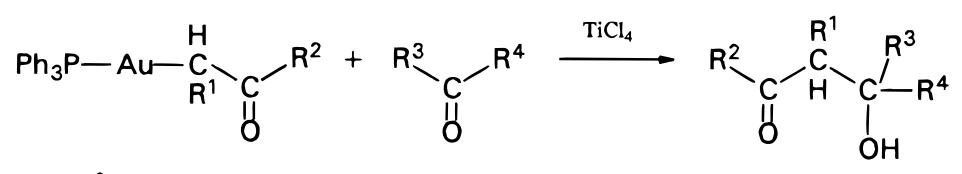<smiles></smiles><smiles>Cc1c2ccccc2c(=O)n2ccccc12</smiles>

$(87 \%)$<smiles></smiles><smiles>O=C1C=CC=CN2C1C(=O)c1ccccc1C2c1c2ccccc2c(=O)n2ccccc12</smiles>

I $(81 \%)$

- $\mathrm{CH}\left(\mathrm{CH}_{3}\right) \mathrm{COOCH}_{3}$, and 2-cyclohexanone reacting with $\mathrm{PhCHO}, \mathrm{PhCH}_{2} \mathrm{CHO}$ or $\mathrm{PhC}(\mathrm{O}) \mathrm{CH}_{3}$.

Heterocyclic ketones can be obtained in good yield by high-pressure $\left(50 \mathrm{~atm}, 60^{\circ} \mathrm{C}\right)$ carbonylation of ortho-metallated benzylpyridine gold(III) complexes (Equations 2, 3) (7). The formation of the diaryl (I, Equation 3) is thought to occur by $\mathrm{C}-\mathrm{Cl}$ activation of (II), which is itself formed by gold(III)-assisted chlorination of the inital product (III); small amounts of (II) and (III) are found among the products. In all these cases, the by-product is metallic gold.

There appears to be considerable scope for further investigation of these and related reactions. The use of gold compounds in stoichiometric reactions is not necessarily prohibitively expensive since, in all but the last of the above examples, discrete gold(I) or gold(III) complexes are formed rather than gold metal; yields are good $(>75 \%)$, and the reactions are clean. It would not be difficult to devise methods for separating these secondary products and transforming them back into the starting materials ( $c f$ reference 3$)$. Calcination of residues to metallic gold is also possible, but this would add several steps to the recycling procedure.

\section{CATALYSIS INVOLVING ORGANOGOLD COMPOUNDS}

Involvement of gold complexes of any type in homogeneous catalysis is very rare. This is in stark<smiles>O=c1c2ccccc2c(Cl)c2ccccn12</smiles>

II $(12 \%)$<smiles>O=c1c2ccccc2cc2ccccn12</smiles>

contrast to the neighbouring precious metals, many of which readily undergo catalytic oxidative-addition / reductive-elimination cycles. The problem is that this type of catalysis requires a very delicate balance between the stabilities of the two oxidation states involved, and this has not yet been achieved for gold. An additional factor is the reluctance of gold to form hydride complexes, so that oxidation of gold(I) by dihydrogen, or the formation of alkene complexes by $\beta$-elimination from gold(III)-alkyl complexes are virtually unknown (there is one case recorded of a tertbutyl iso-butyl isomerization, thought to occur by $\beta$ elimination (8)).

Although gold(I) complexes readily undergo oxidative addition, eg with alkyl halides, the resulting complexes are usually either too stable to react further or so unstable that they react immediately. Reductiveelimination from di- or tri-organogold(III) complexes is either restricted to particular types of organogold complex or requires robust treatment resulting primarily in elimination of hydrocarbons by coupling reactions.

For other metals, the relative stabilities of the two critical oxidation states can be adjusted by appropriate choice of ligands, eg the inclusion of a good $\pi$-bonding ligand, such as CO, increases the stability of the lower oxidation state. In the case of gold, this mechanism is not available, $\pi$-bonding being of relatively little importance.

Gold(I) and gold(III) alkoxides have very recently (9) been shown to catalyse the condensation of 
benzaldehyde with compounds containing an active methylene group, $\mathrm{CH}_{2}(\mathrm{X}) \mathrm{Y}$ (Equation 4). Best results were obtained with gold(I) complexes of the more electron-withdrawing alkoxides: $\mathrm{R}_{3} \mathrm{PAu}\left(\mathrm{OR}^{\prime}\right), \mathrm{R}=\mathrm{Ph}$, $\mathrm{C}_{6} \mathrm{H}_{11} ; \mathrm{R}^{\prime}=\mathrm{CH}_{2}\left(\mathrm{CF}_{3}\right)_{2}$. The proposed mechanism is shown in Scheme 1: the alkoxide IV initially reacts with $\mathrm{CH}_{2}(\mathrm{X}) \mathrm{Y}$ from which it abstracts a proton to form the corresponding alcohol and an $\mathrm{Au}-\mathrm{CH}(\mathrm{X}) \mathrm{Y}$ species $\mathbf{V}$ (such compounds themselves catalyse the reaction, but less efficiently). The carbonyl group of benzaldehyde inserts into the Au-C bond of $\mathbf{V}$ and the resulting complex deprotonates either $\mathrm{CH}_{2}(\mathrm{X}) \mathrm{Y}$ or the alcohol, to reform IV or $\mathbf{V}$; the initially formed alcohol (VI) loses water spontaneously.

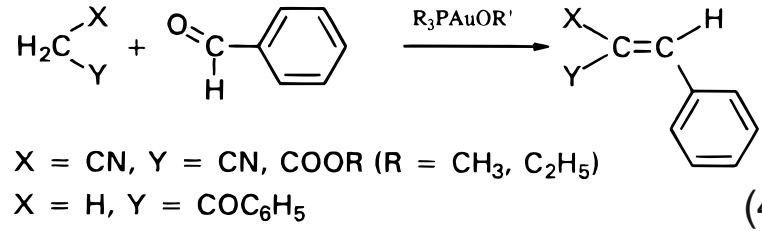

The only other useful example of homogeneous catalysis which appears to involve an organogold intermediate is the cyclization of alkynyl amines $\mathrm{R}^{1} \mathrm{C} \equiv \mathrm{C}\left(\mathrm{CH}_{2}\right)_{3} \mathrm{CHR}^{2} \mathrm{NH}_{2}\left(\mathrm{R}^{1}, \mathrm{R}^{2}=n-\mathrm{C}_{6} \mathrm{H}_{13}, \mathrm{H} ; \mathrm{Et}\right.$, $\mathrm{H} ; n-\mathrm{C}_{5} \mathrm{H}_{11}, \mathrm{Me} ; \mathrm{H}, n-\mathrm{C}_{6} \mathrm{H}_{13}$ ) (Equation 5) catalysed by $\mathrm{Na}\left[\mathrm{AuCl}_{4}\right]$ (10). It was suggested that a cyclic intermediate (VII) is formed by exo-dig addition of $\mathrm{Au}$ and $\mathrm{N}$ across the triple bond which then undergoes protonolysis and isomerization. The reaction mixture rapidly decolourizes, implying the involvement of gold(I), and the most likely mechanism would be via initial formation of a $\pi$-alkyne complex (VIII). The

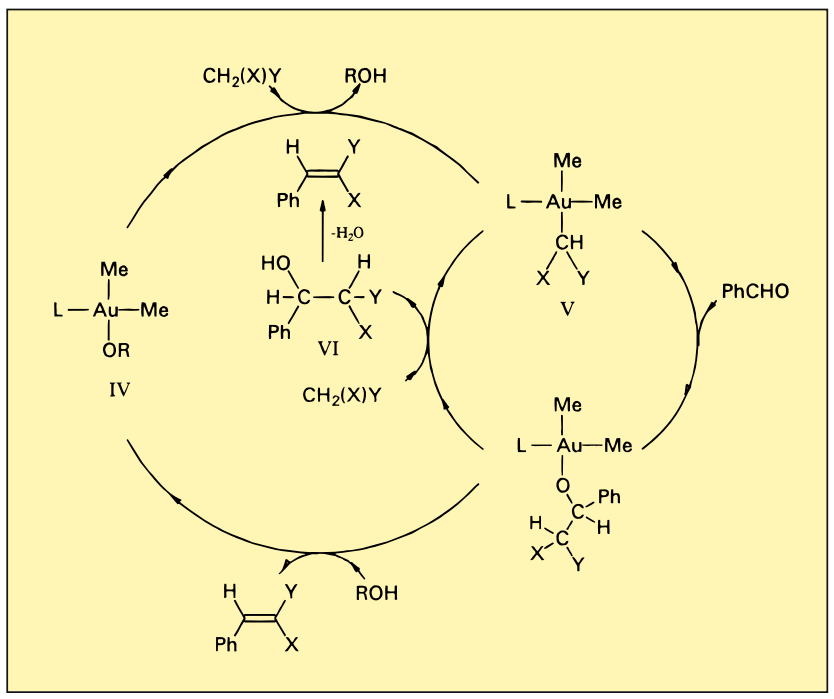

Scheme 1 The Komiya catalytic cycle<smiles>[R]C#CCCC(N)CC</smiles>

(5)

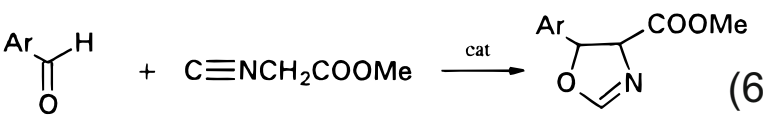

(6)

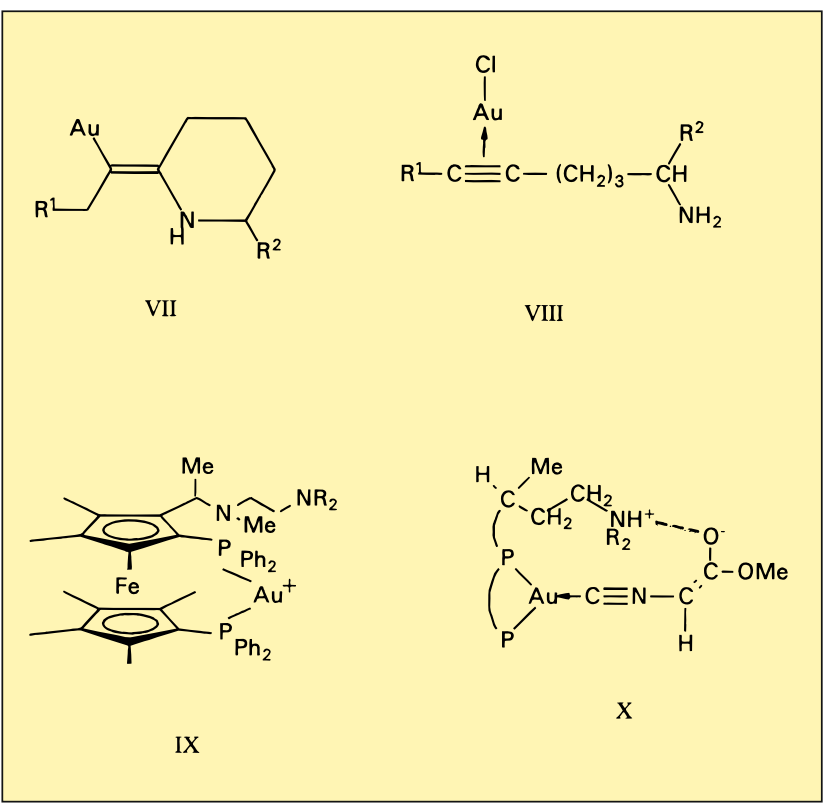

coordinated triple bond would then be open to nucleophilic attack by the amine group; under sufficient dilution, this would occur intramolecularly.

The 'Hyashi' catalyst (IX) which is achieving prominence for synthesis of asymmetric heterocycles (Equation 6) is also a gold(I) complex, although its mode of action involves formation of an isonitrile complex of gold $(\mathbf{X})$, rather than an organometallic intermediate (11). There is some evidence that $\left[\mathrm{AuCl}_{4}\right]^{-}$catalyses the addition of nucleophiles such as amines and alcohols to isonitriles (12) and that the mechanism involves the formation of carbene complexes (13), but in all cases copper(I) is a far better catalyst.

\section{CONJUGATED ROD POLYMERS}

Linear conjugated polymers have potential as molecular 'wires'; for instance, polyacetylene (XI) or poly-p-phenylene (XII) doped with iodine display 


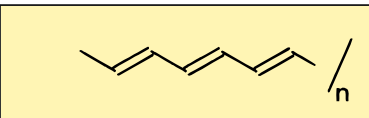

XI

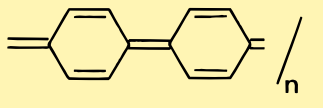

XII considerable electrical conductivity. Since gold(I) usually displays linear coordination it is a possible component of such a conjugated system (14). The 'simple' alkynyls, $[\mathrm{AuC} \equiv \mathrm{CR}]_{\mathrm{n}}$, probably do not give linear polymers, although structural information is available only for $\mathrm{R}=\mathrm{Bu}^{\mathrm{t}}$; in this case, pairs of intercalated hexameric rings are formed (15). A possible improvement is to use an aromatic para-dialkyne to obtain $[-\mathrm{Au}-\mathrm{C} \equiv \mathrm{C}-\mathrm{Ar}-\mathrm{C} \equiv \mathrm{C}-]_{\mathrm{n}}$, which can be obtained from $\mathrm{Me}_{2} \mathrm{SAuCl}$ and the di-yne (16). Alternatively, a para-di-yne may be used in combination with a para-di-isonitrile as the linking group: $\quad\left[-\mathrm{Au}-\mathrm{C} \equiv \mathrm{C}-\mathrm{Ar}-\mathrm{C} \equiv \mathrm{C}-\mathrm{Au}-\mathrm{CNAr}{ }^{\prime} \mathrm{NC}-\right]_{\mathrm{n}} \quad$ (14). The disadvantage of these materials is that they have no well-defined end-groups and are therefore likely to cyclize. This problem might be overcome by using a bifunctional aromatic, such as para- $\mathrm{N} \equiv \mathrm{C}$ $\mathrm{C}_{6} \mathrm{H}_{4} \mathrm{C} \equiv \mathrm{CH}$, to react with a simple gold(I) alkyne complex; heating the resulting monomer yields a polymer (Equation 7) (17).

$$
\begin{aligned}
& \mathrm{Bu}^{\mathrm{t}} \mathrm{C} \equiv \mathrm{C}-\mathrm{Au}-\mathrm{C} \equiv \mathrm{NC}_{6} \mathrm{H}_{4} \mathrm{C} \equiv \mathrm{CH} \longrightarrow \\
& \left.\mathrm{Bu}^{\mathrm{t}} \mathrm{C} \equiv \mathrm{C}-\mathrm{Au}-\mathrm{C} \equiv \mathrm{NC}_{6} \mathrm{H}_{4} \mathrm{C} \equiv \mathrm{C}\right]_{\mathrm{n}} \mathrm{H}
\end{aligned}
$$

All these materials are highly insoluble and therefore very difficult to characterize. Probably for this reason, their doping has not been attempted. Careful choice of dopant will be necessary to avoid stoichiometric oxidative-addition at the gold(I) centres.

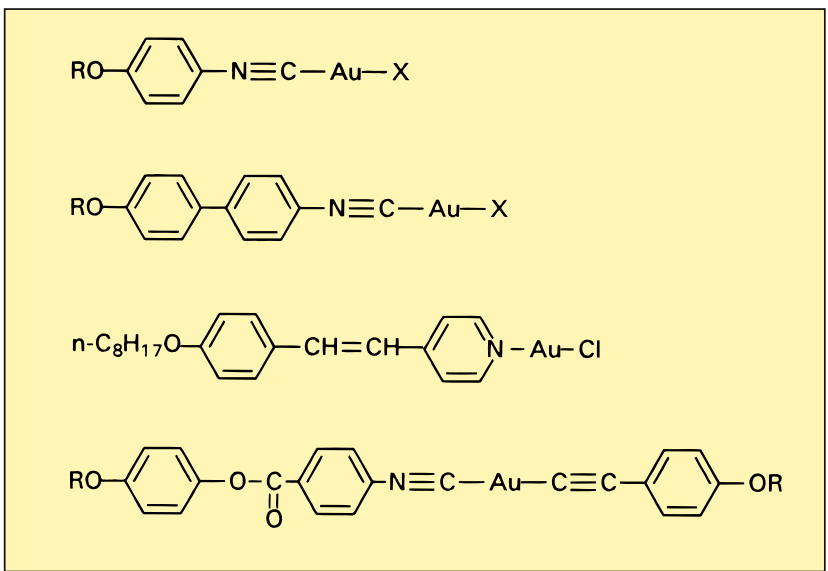

Box 3 Molecules which form liquid crystals

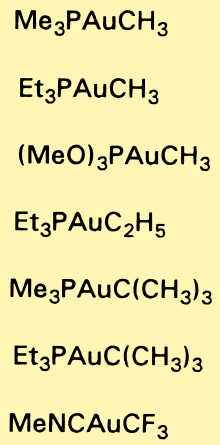

Box 4 Compounds used for MOCVD

\section{LIQUID CRYSTALS 1}

Only a few potentially useful liquid crystalline gold materials have been reported (18-21). They are also based on rod-like molecules. The incorporation of gold(I) gives mesomorphic properties to some molecules which do not exhibit them in the free state; for others, it gives an increase in melting point and a large increase in the temperature ranges of the mesomorphic phases. The gold complexes usually have better thermal stability than the free ligands. Typical materials are shown in Box 3. Systematic studies have been made of the effect on the mesogenic behaviour of the nature of the alkoxy groups and of substituents on the rings.

\section{METAL-ORGANIC CHEMICAL VAPOUR DEPOSITION}

MOCVD is an attractive way of depositing thin layers of various materials, in order to build up semiconductor wafers or to make high-resolution printed circuits. A volatile compound is decomposed thermally on a substrate to deposit a layer of the appropriate material: in the present context, metallic gold. The composition of the deposit must be controllable to stringent limits, and the area of deposition must be well-defined; the latter objective is usually achieved by

1 Some materials composed of large linear or planar molecules form welldefined, highly ordered, liquid (mesomorphic) phases which occur between the solid and the clear, normal liquid. The various phases may have useful opto-electronic properties. There are usually sharp transition temperatures between the various phases. 
masking or by using laser-beam decomposition. A further limitation is imposed by the need in many micro-electronic devices to have sharp concentration gradients across boundaries; this means that undue heating must be avoided in order to minimize diffusion.

It is therefore necessary to find compounds which have good shelf-life, are volatile at modest temperatures and are easily decomposed to give highpurity elemental gold; ease of storage and handling would also be advantageous. Various organogold compounds have been investigated (see Box 4), some getting as far as the patent stage (22-30). The most exploited to date is $\mathrm{Me}_{3} \mathrm{PAuCH}_{3}$, but it is claimed that $\mathrm{MeCNAuCF}_{3}$ has the advantage of being easier to store (26).

Thermal decomposition of volatile gold compounds usually requires temperatures of at least $250^{\circ} \mathrm{C}$, while laser-induced decomposition can be done at lower substrate temperatures (there is, of course, local heating). The latter technique allows the 'writing' of detailed designs, but is rather slow. A very promising route $(23,30)$ allows room-temperature deposition on ultra-clean metal surfaces (chromium is best). It requires an ultra-high vacuum technique to create and maintain sufficiently clean surfaces.

The decomposition of the organogolds on the various substrates is generally thought to follow the same routes as for normal thermal decomposition in solution (Equation 8) (31). This involves dissociation of a ligand to give a coordinatively unsaturated intermediate such as ' $\mathrm{AuCH}_{3}$ ' which reacts with a molecule of undissociated complex to give ethane, the ligand and metallic gold. In this case, the intermediate gold alkyl would be chemisorbed on the metallic substrate (23).

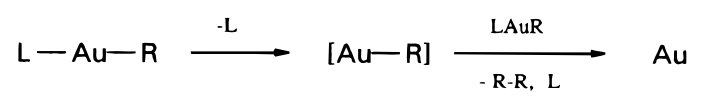

2 Luminescent materials are those which absorb light at one wavelength and re-emit it efficiently at well-defined longer wavelengths. The emission normally occurs very rapidly after excitation, the half-life of the excited state being from picoseconds to milliseconds. Materials were originally classified as fluorescent or phosphorescent on the basis of the lifetime, phosphorescence being the process with the longer lifetimes. Modern usage refers rather to the nature of the excited state: fluorescence involves no change in the electronic spin and de-excitation is rapid; phosphorescence involves a change in the number of unpaired electrons (usually singlet $\longleftarrow$ triplet), and emission is therefore by a spin-forbidden transition, and slow.

\section{LUMINESCENTS ${ }^{2}$}

Many gold(I) compounds show yellow, orange or green emission $(400-500 \mathrm{~nm})$ when irradiated with light corresponding to normal absorption bands in the near ultraviolet $(250-350 \mathrm{~nm})$. The effect is usually more pronounced for the solid material, but can often be seen also for solutions. The half-lives of the emitting states are relatively long, typically 1-30 ms. This, and the large energy separation between the absorbed and emitted radiation (typically 10,000-15,000 $\mathrm{cm}^{-1}$ ) indicates phosphorescence. It seems that the excitation is primarily via metal-to-ligand or intra-ligand transitions; many complexes show similar luminescence to the ligands from which they are derived, although both the intensities and lifetimes may be considerably enhanced. The suggestion that gold-gold interactions are essential seems not to be substantiated (32), although they can modify the wavelength of emission or produce additional bands. In phosphorescence, the formation of an electronically excited singlet state by absorption of light is followed by intersystem crossing-over to a triplet state of lower energy from which de-excitation to the original ground state occurs (Figure 1). Since the final transition is spin-forbidden, it is slow.

Attention has focused largely on tertiary phosphine complexes of gold(I) halides or thiolates, and luminescent organometallic derivatives are relatively rare (or untested). As in other areas of recent chemistry, alknyl derivatives are prominent (33-36), but some $\sigma$-alkyl $(36,37)$ and $\sigma$-aryl $(37)$ derivatives and one benzimidazolate complex are also active (38) (see Box 5 for examples). In nearly all cases, an aryl tertiary phosphine ligand is also involved. The free ligands are themselves phosphorescent, and excitation is thought to be of an electron from the lone pair into a $\pi^{*}$ aromatic-ring orbital $\left(\mathrm{n} \longrightarrow \pi^{*}\right)$. Since the

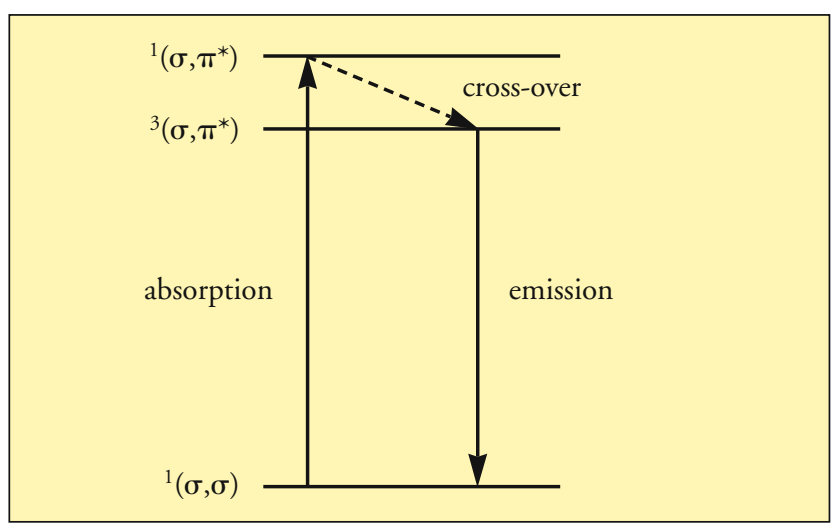

Figure 1 Energy transitions for phosphorescence 


\begin{tabular}{|c|c|c|c|c|}
\hline & $\lambda_{e m} / \mathrm{nm}$ & $r / \mu \mathrm{s}$ & Excited State & Ref \\
\hline $\begin{array}{l}\mathrm{CH}_{3}-\mathrm{Au}-\mathrm{PMe}_{2} \mathrm{PMH}_{2} \\
\mathrm{CH}_{3}-\mathrm{Au}-\mathrm{PMe}_{2}\end{array}$ & $\begin{array}{l}424 \\
485 \mathrm{sh}\end{array}$ & 0.5 & ${ }^{3}\left[d_{\sigma}^{*}, p_{\sigma}\right]$ & (37) \\
\hline $\begin{array}{l}\mathrm{C}_{6} \mathrm{H}_{5}-\mathrm{Au}-\mathrm{PPh}_{2} \mathrm{CH}_{2} \\
\mathrm{C}_{6} \mathrm{H}_{5}-\mathrm{Au}-\mathrm{PSh}_{2}\end{array}$ & $\begin{array}{l}480 \\
600\end{array}$ & 1.0 & $\left.{ }^{3}\left[\mathrm{dg}_{\sigma^{*}, \pi^{*}}(\mathrm{dppm})\right]\right]$ & (37) \\
\hline $\mathrm{C}_{6} \mathrm{H}_{5}-\mathrm{C} \equiv \mathrm{C}-\mathrm{Au}-\mathrm{PPh}_{3}$ & 459 & 33.4 & ${ }^{3}\left[\sigma, \pi^{*}(P)\right]$ & (34) \\
\hline $\mathrm{C}_{6} \mathrm{H}_{5}-\mathrm{C} \equiv \mathrm{C}-\mathrm{Au}-\mathrm{PPh}_{2} \mathrm{Me}$ & 524 & 6.6 & ${ }^{3}\left[\pi, \pi^{*}(\mathrm{C} \equiv \mathrm{C})\right]$ & (34) \\
\hline $\begin{array}{l}\mathrm{C}_{6} \mathrm{H}_{5}-\mathrm{C} \equiv \mathrm{C}-\mathrm{Au}-\mathrm{PPh}_{2} \\
\left.\mathrm{C}_{6} \mathrm{H}_{5}-\mathrm{C} \equiv \mathrm{C}-\mathrm{C} \mathrm{H}_{2}\right)_{2}-\mathrm{PPh} \mathrm{h}_{2}\end{array}$ & 420 & 4.2 & ${ }^{3}\left[\pi, \pi^{*}(\mathrm{C} \equiv \mathrm{C})\right]$ & (33) \\
\hline $\begin{array}{l}\mathrm{C}_{6} \mathrm{H}_{5}-\mathrm{C} \equiv \mathrm{C}-\mathrm{Au}-\mathrm{C} \equiv \mathrm{N}-\mathrm{C} \mathrm{Me}_{2} \\
\mathrm{Cl}_{6} \mathrm{CH}_{2}\end{array}$ & 420 & 2.9 & ${ }^{3}\left[\pi, n^{*}(\mathrm{C} \equiv \mathrm{C})\right]$ & (36) \\
\hline
\end{tabular}

Box 5 Some luminescent materials

spectroscopic profiles of the complexes are similar to those of the ligands, it is assumed that an Au-P bonding electron is promoted $\left(\sigma \longrightarrow \pi^{*}\right)$. The energies of the emission follow the basicity of the ligands, being lowest when high electron density is expected on the gold atom (34). For alkynyl derivatives, the excited state is probably associated with the triple-bond $\pi$-system.

The exited-state complexes are strong reducing agents, and redox potentials of $-1.6 \mathrm{~V}$ and $-2.0 \mathrm{~V}$ have been estimated for XIII and XIV $(36,37)$. Although both the luminescent and reducing properties of these materials have considerable potential for development, none appears yet to have reached the active application stage.

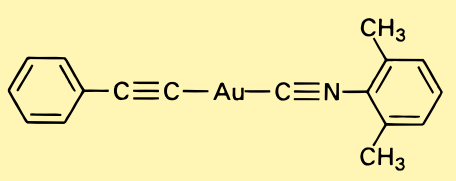

XIII

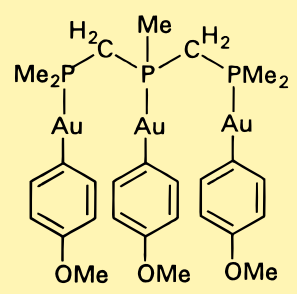

XIV

\section{ANTITUMOURALS}

Since the discovery of the remarkable antitumour activity of cisplatin, a vast number of heavy-metal complexes have been screened. Included in these have been a few gold complexes (39), mostly phosphine gold(I) derivatives, but few have shown useful activity.

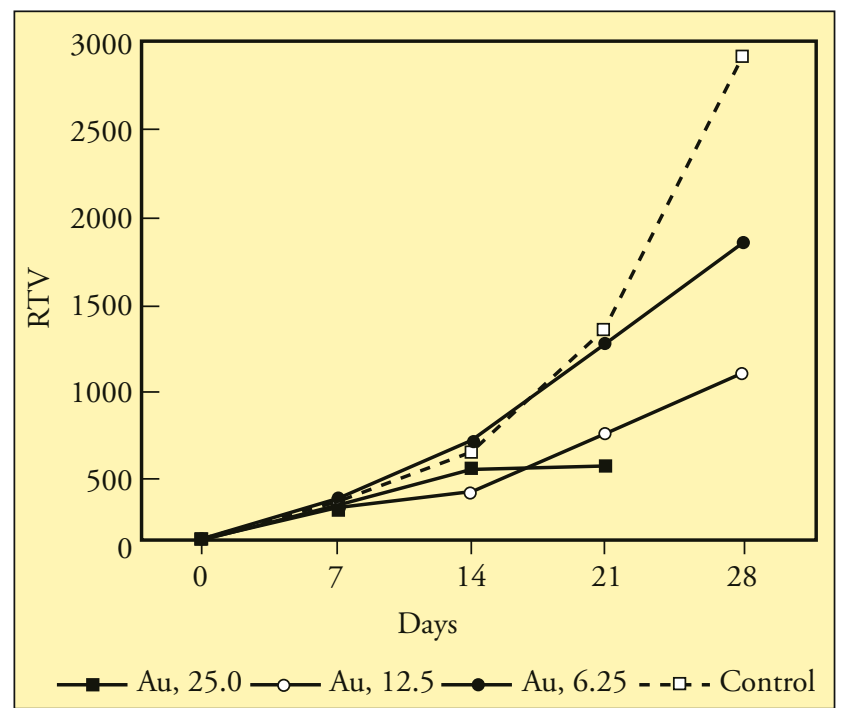

Figure 2a

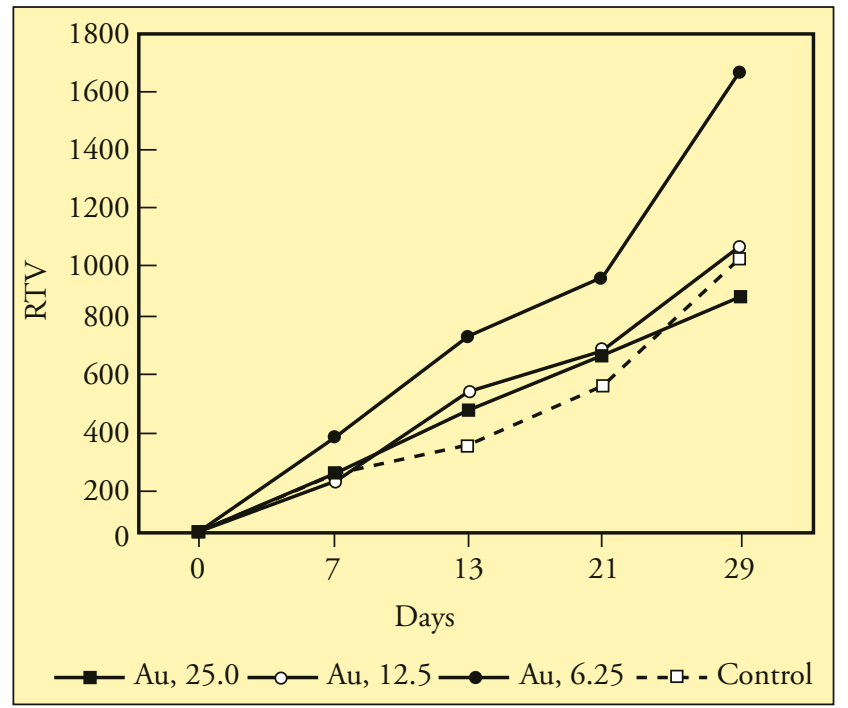

Figure 2b Relative Tumour Volumes (RTV) vs time for ZR-751 tumour xenografts on nude mice. The curves are labelled with the dose levels in $\mathrm{mg} / \mathrm{kg}$. (a) Undosed controls and $\left[\mathrm{AuCl}_{2}(\right.$ damp $\left.)\right]$. (b) [Au(OAc) $)_{2}$ damp] and cisplatin.

The organogold(III) complexes $\left[\mathrm{Ph}_{4} \mathrm{As}\right]\left[\mathrm{Me}_{2} \mathrm{AuCl}_{2}\right]$ and $\left[\mathrm{Me}_{2} \mathrm{Au}(\mathrm{SCN})\right]_{2}$ have been shown to inhibit the growth of the P388 leukemia cells (40). These complexes are somewhat analogous to cisplatin, in having cis configurations with two tightly bound ligands and two which are more labile. Attempts (41) to impose the cis geometry by use of chelating ligands (pyridine 2-carboxylates) gave materials which were readily reduced in biological media. Stability was imparted by use of a softer ligand, and the known (42) complex $\mathrm{AuCl}_{2}$ (damp) [damp = 2dimethylaminomethylphenyl] showed cytotoxicity 
similar to cisplatin against a range of tumour lines (43). In tests against the breast tumour line ZR-75-1 grafted onto living mice, it gave similar profiles to cisplatin although at rather higher doses (see Figure 2a).

The corresponding diacetato complex has much greater aqueous solubility and is rather more effective (see Figure 2b) (43). The analogy to cisplatin is reinforced by the observed hydrolysis behaviour, in which one acetate group is very readily replaced by water, and a second more slowly. The reactivity towards model biological ligands, such as cysteine, glutathione, adenine and adenosine was found to be slightly different from that of cisplatin (44). The formation of inter- and intra-strand links in DNA, however, are not the same as those shown by cisplatin (43), so that the detailed biochemical mechanisms are different; the gold compounds may therefore show a novel spectrum of activity.

\section{CONCLUSION}

Of a variety of applications which have been proposed for organogold compounds, few are yet being vigorously deployed; organic synthesis, catalysis, MOCVD and chemotherapy are promising areas for further work.

\section{ACKNOWLEDGEMENTS}

I am grateful to my colleagues Bob Munn and Dave Berrisford for helpful advice on aspects of luminescence and organic chemistry.

\section{ABOUT THE AUTHOR}

Professor Dick Parish has a personal chair of Coordination Chemistry at UMIST, where he leads a team extending the chemistry of gold, with particular reference to materials of potential medicinal application. He has also worked in Mössbauer spectroscopy and has developed the technique as an excellent method of characterization for gold compounds.

\section{REFERENCES}

$1 \quad$ R.V. Parish, Gold Bull., 1997, 30, 3

2 R.V. Parish, Gold Bull., 1997, 30, 55

3 J. Vicente, M.D. Bermúdez and J. Escribiano, Organometallics, 1991, 10, 3380; J. Vicente, M.D. Bermúdez, F-J. Carrión and P.G. Jones, Chem. Ber., 1996, 129, 1395

4 J. Vicente, M.D. Bermúdez and F-J. Carrión, Inorg, Chim. Acta, 1994, 220, 1
5 T. Sone, S. Ozaki, N.C. Kasuga, A. Fukuoka and A. Komiya, Bull. Chem. Soc, Jpn., 1995, 68, 1523

6 M. Murukami, M. Inouye, M. Suginome and Y. Ito, Bull. Chem. Soc. Jpn., 1988, 61, 3649

7 M.A. Cinellu, A. Zucca, S. Stoccoro, G. Mignhetti, M. Manassero and M. Sansoni, J. Chem. Soc., Dalton Trans., 1995, 2865

8 A. Tamaki, S.A. Magennis and J.K. Kochi, J. Am. Chem. Soc., 1974, 96, 6140

9 S. Komiya, T. Sone, Y. Usui, M. Hirano and A. Fukuoka, Gold Bull., 1996, 29, 131, and references therein

10 Y. Fukada and K. Utimoto, Synthesis, 1991, 975

11 V.A. Soloshonok and T. Hayashi, Tetrahedron Asymm., 1994, 6, 1091, and references therein

12 T. Saegusa, Y. Ito, S. Kobayashi, K. Hirota and H. Yoshioka, Bull. Chem. Soc. Jpn., 1969, 42, 3310

13 J.E. Parks and A.L. Balch, J. Organomet. Chem., 1974, 71, 453

14 M.J. Irwin, G. Jia, N.C. Payne and R.J. Puddephatt, Organometallics, 1996, 15, 51, and references therein

15 D.M.P. Mingos, J. Yau, S. Menzer and D.J. Williams, Angew. Chem., Int. Ed. Engl., 1995, 34, 1894

16 G. Jia, R.J. Puddephatt, J.D. Scott and J.J. Vittal, Organometallics, 1993, 12, 3565

17 G. Jia, N.C. Payne, J.J. Vittal and R.J. Puddephatt, Organometallics, 1993, 12, 4771

18 S. Coco, P. Espinet, J.M. Martín-Alvarez and A.M. Levelut, J. Mater. Chem., 1997, 7, 19

19 T. Kaharu, R. Ishi, T. Adachi, T. Yoshida and S. Takahashi, J. Mater. Chem., 1995, 5, 687

20 M. Benouazzane, S. Coco, P. Espinet and J.M. Martín-Alvarez, J. Mater. Chem., 1995, 5, 441

21 D.W. Bruce, E. Lalinde, P. Styring, D.A. Dunmur and P.M. Maitlis, J. Chem. Soc, Chem. Commun., 1986, 581

22 J. Messelhaüser, E.B. Flint and H. Suhr, Appl. Surf. Sci., 1992, 54, 64

23 M.M. Banasek Holl, P.F. Seidler, S.P. Kowalczyk and F.R. McFeely, Inorg. Chem., 1994, 33, 510

24 J.L. Davidson, P. John, D.K. Milne, P.G. Roberts, M.G. Jubber and J.I.B. Wilson, $A d v$. Mater. Opt. Elect., 1993, 2, 3

25 D. Blessman, A. Gräfe, R. Heinen, F. Jansen, Th. Kruck and C. Terfloth, Mat. Sci. Eng., 1993, B17, 104

26 N.H. Dryden, J.G. Shapter, L.L. Coatsworth, P.R. Norton and R.J. Puddephatt, Chem. Mater., 
1992, 4, 979; P.R. Norton, P.A. Young, Q. Cheng, N. Dryden and R.J. Puddephatt, Surface Sci., 1994, 307, 172

27 D.W. Allen and J. Haigh, Appl. Organomet. Chem., 1995, 9, 83

28 H. Uchida, N. Saito, M. Sato, M. Yake and K. Ogi, Jap. Patent 5-331176, 1993

29 H. Uchida, N. Saito, M. Sato, M. Yake and K. Ogi, Jap. Patent 6-145985, 1994

30 M.M.B. Holl, S.P. Kowalczyk, F.R. McFeely and P.F. Seidler, European Patent 588080 A1, 1994

31 A. Tamaki and J.K. Kochi, J. Organometal. Chem., 1973, 61, 441

32 W.B. Jones, J. Yuan, R. Narayanaswamy, M.A. Young, R.C. Elder, A.E. Bruce and M.R.M. Bruce, Inorg. Chem., 1995, 34, 1996

33 D. Li, X. Hong, C-M. Che, W-C Lo and S-M. Peng, J. Chem. Soc., Dalton Trans., 1993, 2929

34 T.E. Müller, S.W.K. Choi, D.M.P. Mingos, D. Murphy, D.J. Williams and V.W-W. Yam, J. Organomet. Chem., 1994, 484, 209

35 S-J. Shieh, X. Hong, S-M. Peng and C-M. Che, J. Chem. Soc., Dalton Trans., 1994, 3067

36 H. Xiao, K-K. Cheung and C-M. Che, J. Chem. Soc., Dalton Trans., 1996, 3699
37 V.W-W. Yam and S.W-K. Choi, J. Chem. Soc., Dalton Trans., 1994, 2057

38 B-C. Tzeng, D. Li, S-M. Peng and C-M. Che, J. Chem. Soc., Dalton Trans., 1993, 2365

39 O.M. ni Dubhghiall and P.J. Sadler, in Metal Complexes in Cancer Therapy (ed. B.K. Keppler), VCH, Weinheim, 1993, p221.; C.F. Shaw, in Metal Compounds in Cancer Therapy (ed. S.P. Fricker) Chapman and Hall, London, 1994, p.46

40 P.J. Sadler, M. Nasr and V.L. Narayanan, in Platinum Coordination Complexes in Cancer Therapy (ed. M.P. Hacker, E.B. Douple and I.H. Krakoff), Martinus Nijhoff Publishing, Boston, 1984, p. 290

41 A. Dar, K. Moss, S.M. Cottrill, R.V. Parish, C.A. McAuliffe, R.G. Pritchard and B. Beagley, J. Chem. Soc., Dalton Trans., 1992, 1907

42 J. Vicente, M.T. Chichote, M.D. Bermúdez, J. Organomet. Chem., 1984, 268, 191

43 R.G. Buckley, A.M. Elsome, S.P. Fricker, G.R. Henderson, B.R.C. Theobald, R.V. Parish, B.P. Howe and L.R. Kelland, J.Med. Chem., 1996, 39, 5208; S.P. Fricker, Gold Bull., 1996, 29, 53

44 R.V. Parish, J. Mack, L. Hargreaves, J.P. Wright, R.G. Buckley, A.M. Elsome and B.R.C. Theobald, J. Chem. Soc., Dalton Trans., 1996, 69

\section{Special Book Offer}

\section{GOLD ALLOYS - TERNARY PHASE DIAGRAMS}

The Institute of Materials, London, wishes to clear its stocks of the book, 'Phase Diagrams of Ternary Gold Alloys' by A.Prince, G.V. Raynor and D.S.Evans, published in 1990. World Gold Council has negotiated a special once-only price

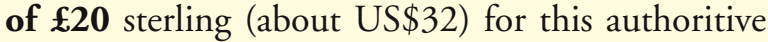
reference book - a dramatic reduction from the original price of $£ 125$. At this price, you can afford to have your own personal copy.

Good phase diagrams are the basic tools of metallurgists and are essential to the understanding of alloy microstructure and their influence on properties. This excellent book, therefore, is a 'must' for anyone working with gold alloys, be it for jewellery, dentistry, electronics, brazing and soldering or other applications of this unique metal.

Orders for the book should be sent, with payment (credit cards accepted) to :
The Institute of Materials, Publications Dept., 1 Carlton House Terrace, London SW1Y 5DB U.K. Tel: +441718394071 Fax: +441718391702

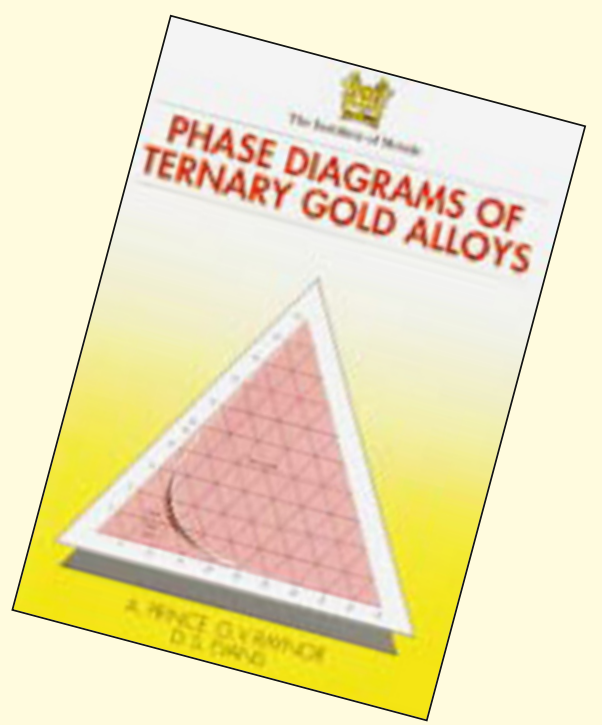

